\title{
Searchable Database for Physician CMS Payments
}

Earlier this month the Centers for Medicare and Medicaid Services (CMS), despite the objections of many physicians, released physician payment data for 2012 (1). However, the data on the CMS website is difficult to search and interpret. The New York Times created a searchable database of physician payments from CMS which can be searched by physician name, specialty and/or location (2). The Times points out that payments may cover overhead, such as staff salaries and drug costs. In some cases, when doctors work as salaried employees of group practices, the payments that show up under their names go to their institutions.

Richard A. Robbins, MD

Editor

\section{References}

1. CMS. Medicare Provider Utilization and Payment Data: Physician and Other Supplier. Available at: https://www.cms.gov/Research-Statistics-Data-andSystems/Statistics-Trends-and-Reports/Medicare-Provider-Charge-Data/Physicianand-Other-Supplier.html (accessed 4/24/2014).

2. NY Times. How Much Medicare Pays For Your Doctor's Care. Available at: http://www.nytimes.com/interactive/2014/04/09/health/medicare-doctordatabase.html (accessed 4/24/2014). 